\title{
The Power Generation Planning of Wind Energy
}

\author{
Mehmet Göksu' ${ }^{1}$, Mehmet Kiraz ${ }^{1}$ and Ahmet Kılıçkan ${ }^{2 *}$ \\ ${ }^{1}$ Institute of Natural and Aplied Science, Turkey \\ ${ }^{2}$ Department of Biosystem Engineering, Adnan Menderes University, Turkey \\ *Corresponding author: Ahmet Kılıçkan, Adnan Menderes University, Faculty of Agriculture, Department of Biosystem Engineering, Aydın, Turkey
}

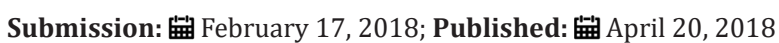

\begin{abstract}
Theuse of windenergythroughoutthehistoryandtheintegration of modern powersystemswithwindenergy has becomeone of themostimportantissues as it takesitsplace in today'senergysector. In this union, the variable behavior of the winds was a problem for the power systems to work in integrated with the wind energy due to the regular and continuous energy needs. These problems are tried to be minimized by some wind energy estimation models and programs.

In this study, it is aimed to provide information about wind energy models and programs that are used tomake power production estimations for scientific purposes and applications. Power estimation models offer the most common physical and statistical and hybrid methods. These models are processed by computer programs such as Wasp, Windpro, WindFarmer, Windographer, Homer, Reisreen, and Windsor.
\end{abstract}

\section{Introduction}

One of the main needs of economic and social development is energy production. The increase in energy use, which is the main input of all economic activities, brings with it an increase in energy demand. The use of fossil fuels for energy production, industry, transportation and heating and the carbon dioxide and other greenhouse gases that are released into the atmosphere cause global warming and climate change. With global warming, local and regional environmental problems such as air, water and soil pollution have accelerated the development of sustainable and renewable energy generation technologies, especially in energy production. In this context, clean and renewable energy sources that are widely applied all over the world are wind energy at the press conference [1].

Wind is made up of temperature and pressure difference caused by the warming and cooling of the atmosphere. Wind is a stable, reliable, and constantly kinetic energy source. The gross kinetic energy of the atmosphere is approximately $190 \times 109 \mathrm{~kW}$. There is an opinion that a third of the kinetic wind power potential of $3 \times 109 \mathrm{~kW}$ between the $50^{\circ}$ northern and southern latitudes of the world can be used. It is estimated that approximately $2 \%$ of the total solar energy that the earth receives is transformed into kinetic energy of the wind. Wind energy is a renewable energy source. Wind energy depends on winds peed. Wind turbines can produce energy in certain wind speed ranges. This is why it is important to know the potential of wind energy in the region where wind turbines will be installed. Wind energy, in fact, mankind M. He.
Starting from the time of Babylonian 2800, it is one of the oldest sources of energy used in irrigation, then in vertical-axis wind mills to grind wheat and electricity generation in the 1900s. Wind Energy has been used in rural areas for the purpose of pumping more water and generating electricity until recent years. Today, the energy sector has taken its place as an alternative source of energy production [2].

\section{Wind Energy Estimatıon Methods and Models}

Wind power is an important tool in the production of energy expected from wind turbines. These estimates are based on physical, statistical, or combination of these two [3]. These estimates are obtained from measurements in the region to be estimated. The measurements are based on the data obtained from the Anemometer, windmill, Thermometer, humidity meter and pressure meter established in the region where the energy is determined. Wind energy estimation varies from region to region. The geographical location is effective in the fact that these estimates are different. For this, different fore casting and modeling are required for each region.

Some areas of use of wind fore casting are as follows:

\section{Wind energy applications}

a) Construction anderectionsector

b) Tourismsector

c) Sports activities 

d) Aviation
e) Maritime
f) Agriculture

\section{Wind power prediction is divided into 4 categories as time maturity [4]}

a) Ultra Short-term forecasts: from a fewseconds to 30 minutes

b) Short-term forecasts: from 30 minutes to 6 hours

c) Mid-term forecasts: from 6 hours to 24 hours

d) Long-term forecasts: from 1 day to 7 days

\section{In general, wind energy estimation methods are divided into five types [3].}
a) Continuity Method
b) Physical Method
c) Intuitive Method
d) Statistical Methods
e) Hybrid Method

Wind energy potential, speed, time, etc. calculations of estimations and models are performed with the help of computer programs in a more healthy and accurate way. Many different computer programs are used to perform these calculations. The seven most commonly used programs are Wasp, WindPRO, WindFarmer, Windographer, Homer, Reiscreen, and Windsim.

\section{WAsP}

Wasp (the Wind Atlas Analysis and Application Program) program was created in 1987 by DTU Risø National Laboratory Wind Energy and Atmospheric Physics Department. Wind data analysis, wind Atlas generation, wind speed estimation, wind field energy calculations and turbine settlement operations are performed through this program [5].

\section{Wind PRO}

Windpro was developed by the Danish wind energy consulting firm EMD. Windpro, similar to wasp, consists mainly of five different modules for wind data analysis, energy production, wind farm calculations, network analysis, environmental impact, economic analysis, etc. and approximately twenty modules for Energy, Environment, economy, electricity, animation and so on [5].

\section{Windographer}

Windographer is developed by Canadian company Mistaya Engineering, who studies renewable energy.

The program focuses on wind data analysis in general. Easy loading of raw data, graphical comparison using these data, control of data and statistical analysis are some of the main features of the program [5].

\section{Homer}

A hydrogen fuel cell is an electrochemical cell that is used to generate electricity from a fuel cell. In Homer, statistical data is entered into the system and calculated. The program is preferred because it facilitates economic comparison of systems. It is one of the biggest advantages of Homer's program that shows how it affects output, i.e. production, and how it makes a difference economically. The main topics of the program consist of simulation, optimization and precision analysis [5].

\section{RET Screen}

RET Screen is one of the programs used in pre-feasibility and feasibility studies of international clean energy project analysis. It can be used in many areas such as energy production, economic life and costs, green house gas emissions. The main reasons for choosing are that it is easy to use and the interface is simple. Solar energy is a complex program that can be used to calculate solar radiation coming to a certain surface, calculations for passive solar heating system, risk analysis of an investment, etc. [5].

\section{Windsim}

Windsim is a wind farm design program developed by Arne Gravdahl in 2003 under the Norwegian wind Atlas project. CFD (Computational Fluid Dynamics) to overcome challenges in complex areas. In this method, non-linear Navier-Stokes equations were solved and more consistent modeling of complex areas was achieved. The effects of turbulence, variable air density, topography and surface shapes on wind speed are more consistent with CFD. The program mainly consists of six modules: field, wind Data, Objects, results, wind maps and wind Power [5].

\section{Conclusion}

Wind speed and power estimation, wind farm establishment and the energy to be obtained from these farms has a very important place in the calculation. There are several methods in the determining this wind energy potential. The most commonly used methods are statistical, physical and the common methods of these two. Specifically, using these methods WaSP, WindFarmer, Windsim, etc. Created with the help of programs such as ewind, AWPPS, WPPT, Zephyr, SOWIE, etc such models have been created. With these models created, estimates were made between one minute and fourty hours. These estimates have achieved 95-99.6\% success.]

\section{References}

1. Dündar C, Oğuz K, Dokuyucu K, Bacanlı H (2011) Kısa Süreli Rüzgar Enerjisi Tahmini.

2. Kurban M, Hocaoğlu FO, Kantar YM (2007) Pamukkale University. Journal of Engineering Sciences 13(1): 103-109.

3. Rakesh Chandra D, SailajaKumari M, Sydulu M (2013) A Detailed LiteratureReview on Wind Forecasting. 2013 International Conference on Power, Energy and Control pp: 630-634.

4. Selvi ŞB, Yıldız M, Akın E (2016) EMoFS Tekniği Kullanılarak Rüzgar Gücü Tahmini Yapılması.

5. Güzel S (2014) Rüzgar Enerjisi Potansiyel Hesaplamasında Kullanılan Bilgisayar Programlarının Karșılaștırılması. 
Creative Commons Attribution 4.0 International License

For possible submissions Click Here

Submit Article MCDA $\begin{aligned} & \text { Modern Concepts } \\ & \text { a Developments } \\ & \text { in Agroonomy }\end{aligned}$

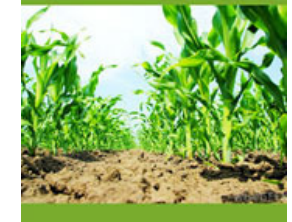

Modern Concepts \& Developments in Agronomy

\section{Benefits of Publishing with us}

- High-level peer review and editorial services

- Freely accessible online immediately upon publication

- Authors retain the copyright to their work

- Licensing it under a Creative Commons license

- Visibility through different online platforms 